\title{
USE OF HOMRA POWDER IN SELF-COMPACTING CONCRETE
}

\author{
Sabry A. Ahmed \\ Lecturer, Faculty of Engineering, Zagazig University, Zagazig, Egypt
}

\begin{abstract}
Although $5-10 \%$ of the production of clay bricks in Egypt is considered as wastes, their use in concrete is still limited. This study investigates the use of homra powder as a partial replacement of cement and the influence of the total powder content on the properties of selfcompacting concrete (SCC). The cement content for concrete mixes ranged from 250 to 400 $\mathrm{Kg} / \mathrm{m}^{3}$ and that of powdered homra from zero to $150 \mathrm{Kg} / \mathrm{m}^{3}$, in order to obtain a total powder content of $400 \mathrm{Kg} / \mathrm{m}^{3}$. A Viscocrete admixture is introduced in these mixes with three different contents: $1,1.5$ and $2 \%$ of the total powder content. In addition to the $400 \mathrm{Kg} / \mathrm{m}^{3}$ total powder content three other contents of 500,550 and $600 \mathrm{Kg} / \mathrm{m}^{3}$ with $2 \%$ of the total powder content superplasticizer are studied and compared with that of $400 \mathrm{Kg} / \mathrm{m}^{3}$. The selfcompactability of concrete is measured by means of slump flow, V-funnel, L-box and resistance to segregation tests. Also the influence on the compressive strength is studied using cubes poured without any internal or external compaction. The results showed that the optimum dosage of Viscocrete admixture in SCC with a total powder content of $400 \mathrm{Kg} / \mathrm{m}^{3}$ is $2 \%$ of the total powder content, irrespective of the amount of cement. Addition of homra powder as a partial replacement of cement resulted in a slight reduction in the concrete flowability, noticeable decrease in compressive strength and prolonged initial and final setting times of concrete. The use of high powder content $\left(500-600 \mathrm{Kg} / \mathrm{m}^{3}\right)$ with $2 \%$ superplacticizer resulted in a concrete with high flowability and moderate viscosity that are necessary for the successful casting of SCC.
\end{abstract}

Keywords: Self-Compacting Concrete, Homra Powder, Flowability, Viscosity, Compactability, Resistance to Segregation.

\section{INTRODUCTION}

The required workability for casting concrete depends on the type of construction, the selected placement and the consolidation method, the shape of formwork and the degree of congestion of the reinforcement. With the increasing use of congested reinforcement, such as in ductile columns in seismic areas, mat foundations, moment-resisting frames and some repair sections, there is a growing need to use highly flowable concrete to ensure proper filling of the narrow and difficult to access areas. Self-compacted concrete (SCC) is a highly flowable concrete that can be spread into place under its own weight and achieve good consolidation without the need for vibrating compaction and without exhibiting defects due to segregation and bleeding. The method of achieving self-compactability involves not only high

Manuscript received from Dr. Sabry . A.Ahmed

Accepted on : 8/ 9/2002

Engineering Research Journal Vol 25, No 4, 2002 Minufiya University, Faculty Of

Engineering, Shebien El-Kom, Egypt, ISSN 1110-1180 


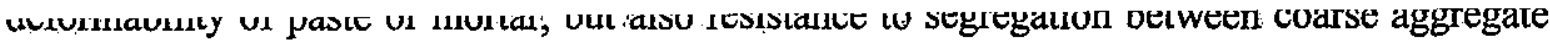
and mortar when the concrete flows through the confined zones of reinforcing bars. To combine these properties it is necessary to have complete control over the rheology of the concrete, the yield value has to be reduced while the plastic viscosity of the fresh concrete has to remain the same. Within the concept of the traditional concrete, this seems impossible. The reduction of the yield value can be realized by adding more water to the mixture but this also reduces the plastic viscosity. In the study of Okamura and Ozawa, the self-compactability was achieved by limiting the coarse aggregate content in combination with low water content and using superplasticizer [1]. Other important factors that affect properties of self-compacted concrete are nominal maximum size (NMZ) of coarse aggregate, dosage of viscosity enhanced admixtures (VEA) and inclusion of fibers [2-5].

$\therefore$ One of the consequences of reducing coarse aggregate content is increasing the mortar and paste content. This result in self-compacting concrete with a powder content considerably higher than that in traditional concrete. High cement content may cause defects such as high shrinkage potential and high heat of hydration in certain types of structures. Therefore, substitution of part of the powder by a less reactive powder than cement is necessary [6]. For this purpose, mineral admixtures such as fly ash, limestone powder, ground granulated blastfurnace slag and silica fume are often used to produce self-compacting high performance concrete in order to improve its strength, workability and durability and to reduce the cost as well [7-11]. In some studies the use of recycled concrete powder and superfine sand were investigated [12-14].

In this study, the use of homra powder in: self-compacting concrete will be investigated in more detail. Homra is a solid waste material produced from the manufacture of clay bricks. These crushed portions of homra are not for commercial use or value and may be considered as a solid waste to environment. Crushed clay materials have been used as aggregate in concrete since the Roman times. In modern times bricks aggregate is used in some refractory concrete and sometimes as a medium-weight aggregate for structural concrete [15]. In Egypt, about $5-10 \%$ of the product of clay bricks are considered as a waste. This solid material consists of vitreous material and may contain $\mathrm{Si}, \mathrm{Al}, \mathrm{Fe}$ and $\mathrm{Ca}$ or some of them. Extensive studies for the effect of addition of homra to Ordinary Portland Cement (OPC) blend were performed up to 90 days of hydration [16-20]. These studies showed that the ground clay bricks exhibit a significant pozzolanic activity equivalent to that of pulverized fly ash (pfa). The replacement of OPC by $20 \%$ weight of homra increases the compressive strength of OPC paste by about $25 \%$ and improves its thermal stability at temperatures between $100-400{ }^{\circ} \mathrm{C}$. Also, it is expected to be resistant to aggressive media such as sulphates and chlorides when blended with Portland or sulphate resisting cement. Therefore, homra can be used in the manufacture of low. cost filled pozzolanic cement or acts as filler in filled pozzolanic cement [18].

The work presented in this investigation is divided into two stages; the first stage is aimed at optimizing the dosage of viscosity-enhancing agent that can be used in concrete with normal powder content $\left(400 \mathrm{~kg} / \mathrm{m}^{3}\right)$ to get high flowability and high segregation resistance. In the second stage, the high flowability and segregation resistance are obtained by using high powder content in combination with superplasticizer, without using any viscosity-enhancing agent. 


\section{EXPERIMENTAL PROGRAM}

\section{Materials and Mix Proportions}

The concrete mixes investigated in this study are prepared with Ordinary Portland: Cement from Suez Cement Company. The crushed clay bricks (homra) are ground to Blaine surface area of about $3000 \mathrm{~cm}^{2} / \mathrm{g}$, which is equal to the specific surface area of cement: The : mineralogical composition of the homra can be seen from the X-ray diffraction pattern (XRD) pattern in Fig. 1. It is clear from the figure that the homra constitutes are mainly free silical: quartz and amorphous alumino-silicate from the decomposition of clay minerals as well as." anorthite, anhydrite and hematite [18]. It contains high contents of silica from the added sand and from the clay. Clay bricks are made from $70 \%$ natural clays and $30 \%$ sand, then mixed with each other by water to give a suitable workability, compressed, dried and fired between $900-1000^{\circ} \mathrm{C}$. The chemical composition of OPC and homra used in this work and clay from which the clay bricks were made is shown in Table 1 . Continuously graded crushed limestone aggregates (dolomite) with a NMZ of $14 \mathrm{~mm}$ and well-graded quartz sand with a fineness modulus of 2.75 are employed. The specific gravity of the coarse aggregate and sand were 2.66 and 2.56 , and their absorption percentages were 1.9 and $1 \%$, respectively.

Two types of chemical admixtures are used namely: Viscocrete-5-400 and SikamentNN from Sika. The Viscocrete-5-400 complies with ASTM C494 types G and F, and has a dual action where it gives excellent flowability and in the same time enhances the stability (viscosity) of concrete. The Sikament-NN complies with ASTM C494 types F and B.S. 5075 part 3 for superplasticizer, and it provides substantial improvement in workability without increasing the mixing water.

The mix proportions of the seven concretes investigated are shown in Table 2 . To be able to make a comparison between the different mixes, the contents of sand $(<5 \mathrm{~mm})$, coarse aggregate $(5-14 \mathrm{~mm})$ and water are kept constant at 900,800 and $200 \mathrm{Kg} / \mathrm{m}^{3}$, respectively. Also, the sand to coarse aggregate ratio by weight is kept constant at 1.125 . In the first four mixes, from 1 to 4 in Table 2, the powder content (cement + powdered homra) is kept constant at $400 \mathrm{Kg} / \mathrm{m}^{3}$. Four cement contents are investigated; 400, 350, 300 and 250, therefore, the powdered homra content is increased from zero to $150 \mathrm{Kg} / \mathrm{m}^{3}$. Three amounts of Viscocrete-5-400 are investigated for each mix: $1,1.5$ and $2 \%$ of the total powder content to obtain the optimum dose that satisfies the required workability and gives high segregation resistance. In the last three mixes, from 5 to 7 in Table 2, the cement content is kept constant at $350 \mathrm{Kg} / \mathrm{m}^{3}$, while the total powder content was 500,550 and $600 \mathrm{Kg} / \mathrm{m}^{3}$. This means that the contents of homra were 150,200 and $250 \mathrm{Kg} / \mathrm{m}^{3}$, respectively. In these mixes, the Sikament-NN is used to obtain the high flowability, while the high segregation resistance is tried by using high powder content and without using a viscosity-enhancing agent. The amount of Sikament-NN is kept constant at $2 \%$ of the total powder content.

\section{Experimental Procedures}

The mixing procedure consisted of mixing all dry materials till obtaining a homogeneous mix (about $60 \mathrm{sec}$.), and then $2 / 3$ of the gauging water is added gradually while the mixer was rotating, and the concrete is mixed for $120 \mathrm{sec}$. The admixture is then added to the remaining water (1/3 of the gauging water) and introduced gradually over 30 sec., and the concrete is mixed for another $120 \mathrm{sec}$. To determine the flowability and viscosity of each mix the slump flow, V-funnel, L-box and segregation tests are used. The slump flow is measured immediately after mixing; afterwards the. $V$-funnel efflux time is determined followed by the L-box test. 
The slump flow test is used to evaluate the consistency of concrete. It consists of filling a normal slump cone (used for traditional concrete) without consolidation, then slowly removing the cone and allowing the concrete to spread under its own weight. The diameter of the concrete is determined as the mean of two orthogonal diameters. Because of the viscous nature of SCC, the measurements are made after there was no more discernible movement of the concrete, approximately 60 seconds after the removal of the slump cone. At the same test the T50 slump flow time is measured when the concrete reached a spread of $500 \mathrm{~mm}$ diameter, and in order to obtain an impression of the degree of horizontal segregation, the segregation of aggregates near the edges of the spread out concrete is observed.

The ability of concrete to change its flow-direction and to pass through narrow spaces without blocking the flow is measured using the V-funnel test, shown in Fig. 2. The funnel is filled completely with concrete to its top edge, and the bottom outlet gate is opened allowing the concrete to flow out. The efflux time, which is the time between opening of the outlet gate and the moment when light can be seen through the opening from above, is measured.

The L-box test, shown in Fig. 3, is used to measure the deformability and blocking of concrete. The vertical part of the L-box apparatus is filled completely with concrete without any consolidation, after that the separating gate is opened and the concrete flows out of the vertical part into the horizontal part through the reinforcing bars that being separated by $40 \mathrm{~mm}$ gap [21]. The end of the horizontal part of the L-box apparatus is removed to enable the concrete to spread for a distance greater than $1.5 \mathrm{~m}$, if necessary. The times for the leading edge of the concrete to reach 40,60 and $80 \mathrm{~cm}$ along the horizontal part are measured to assess the average speed of deformability. The maximum spread distance from the gate (Lmax) is also measured to assess the deformability capacity of the concrete. The average surface gradient $(\mathrm{H} / \mathrm{L})$ is calculated to evaluate the self-leveling property of the concrete as follows:

$$
\mathrm{H} / \mathrm{L}=(\mathrm{H} 1-\mathrm{H} 2) /(\mathrm{Lmax}-10 \mathrm{~cm})
$$

Where: $\mathrm{H} 1$ is the height of concrete at the gate,

$\mathrm{H} 2$ is the height of concrete at $10 \mathrm{~cm}$ away the end of spread out concrete, and

Lmax is the maximum spread out length of concrete.

The resistance of concrete to segregation is measured by pouring a short column $(11 \mathrm{~cm}$ diameter and $40 \mathrm{~cm}$ height) and left until starting to set, after which slices $(11 \mathrm{~cm}$ diameter and $5 \mathrm{~cm}$ height) are taken from the upper and the lower sections. Coarse aggregate of each slice are washed through $5 \mathrm{~mm}$ sieve and weighed. When the difference between the lower and upper sections is lower than $10 \%$, there is no segregation in self-compacting concrete [22].

To measure the compressive strength of self-compacting concrete, three $15 \times 15 \times 15 \mathrm{~cm}$ cubes are prepared for each mix without any internal or external compaction, cured by immersing in water and tested after 28 days.

\section{RESULTS AND DISCUSSION}

Results of the slump flow tests are shown in Figs. 4 through 6. Figure 4 shows the slump flow diameter as a function of the contents of Viscocrete admixture. This figure shows that the flowability of mixes 2-4 containing homra powder is slightly lower than the flowability of mix 1 using cement only. There is no change between the flowability of mixes having different combination of homra powder with the cement. Also, it is clear that the slump flow 
diameter of all mixes increased with the increase of admixture content, and $2 \%$ admixture content yielded slump flow diameter more than $620 \mathrm{~mm}$. Figure 5 shows the time required for the concrete to reach a $500 \mathrm{~mm}$ slump flow diameter (T50) for different mixes and different contents of Viscocrete admixture. As can be seen in this figure, all mixes containing homra powder needed a prolonged time to reach a $500 \mathrm{~mm}$ diameter compared to that of the cement mix. This time is decreased with increasing the admixture content. Considering the effect of the powder content (Fig. 6), it is clear that increasing the powder content have little effect on the flowability of concrete. The slump flow diameter of the mix containing $500 \mathrm{Kg} / \mathrm{m}^{3}$ powder was $627.5 \mathrm{~mm}$ and reached to $645 \mathrm{~mm}$ when the powder content increased to 600 $\mathrm{Kg} / \mathrm{m}^{3}$. However, the increase in the powder content induced a pronounced increase in the slump flow time (T50), as shown in Fig. 7. The slump flow time (T50) of the mix containing $500 \mathrm{Kg} / \mathrm{m}^{3}$ powder was 4.6 seconds and reached to 13 seconds for the mix containing 600 $\mathrm{Kg} / \mathrm{m}^{3}$ powder (i.e. $\approx 3$ times $\mathrm{T} 50$ of $500 \mathrm{Kg} / \mathrm{m}^{3}$ powder content mix). This may be attributed to the fact that the viscosity of the mix by increasing the powder content. Based on the results of the slump flow tests, it can be concluded that replacing a part of cement by homra powder resulted in a slight reduction in the concrete flowability. Regardless of the cement content; the optimum dosage of viscosity admixture was $2 \%$ of the total powder content. A pronounced observation in the slump flow test for all tested mixes is that there was no horizontal segregation of coarse aggregates near the edges of the spread out concrete. This observation reflecting the enhanced viscosity and stability of all mixes regardless of the powder and admixture contents.

The V-funnel test results of the different concrete mixes with different contents of powder and Viscocrete admixture are shown in Figs. 8, 9. In general, these figures show the same phenomenon as the case of slump flow time (T50). Again, the increase in the dosage of admixture resulted in a decrease in the efflux time of the concrete mix (Fig. 8). The efflux time was considerably higher for mix 3 than for mixes 1,2 and 4. However, there was no correlation between the efflux times of the different combination of homra with cement. Also, the increase in the powder content resulted in increasing the efflux time of the concrete mix (Fig. 9). This increase depends on the powder content, e.g. when the powder content is increased from 400 to $500 \mathrm{Kg} / \mathrm{m}^{3}$ the efflux time is slightly increased from 5.8 to 6 seconds, while a noticeable increase in the efflux time is observed at 550 and $600 \mathrm{Kg} / \mathrm{m}^{3}$, which are 9.7 and 11.6 seconds, respectively. The high efflux time is related to the high viscous nature of mixes with high powder content, while the short efflux time resulted from the reduction in the inter-particle friction as a result of the increase in the admixture content.

The experimental results of the L-box test obtained from the testing of mixes type 1 to 4 are shown in Figs. 10 through 12. These figures indicate that the velocity of spread and maximum spread distance (Lmax) of concrete are significantly increased with increasing the dosage of Viscocrete admixture, while the average surface gradient $(\mathrm{H} / \mathrm{L})$ is significantly decreased. At $2 \%$ admixture content the velocity, Lmax and $H / L$ ratio of the four mixes were $25 \pm 3 \mathrm{~cm} / \mathrm{sec}, 126-149 \mathrm{~cm}$ and $4.5 \pm 0.5 \%$, respectively. These results reflecting the excellent deformability without blockage among closely spaced obstacles and the capability of highly flowable concrete to self-consolidate. The use of high powder content showed a significant reduction in the velocity of concrete spread, as shown in Fig. 13. The reduction reached about 38,59 and $73 \%$ for 500,550 and $600 \mathrm{~kg} / \mathrm{m}^{3}$ total powder content, respectively, as compared with the $400 \mathrm{Kg} / \mathrm{m}^{3}$ total powder content. Figures 14,15 show the maximum spread distance and $\mathrm{H} / \mathrm{L}$ ratio of mixes containing high total powder content. These figures show that increasing of the total powder content from 400 to $500 \mathrm{~kg} / \mathrm{m}^{3}$ induced a decrease in the maximum spread distance and an increase in $\mathrm{H} / \mathrm{L}$ ratio. However, marginal or negligible changes are observed in the maximum spread distance $(132-138 \mathrm{~cm})$ and $H / L$ ratio $(4.5-4.9 \%)$ 
of mixes containıng $5 U U-6 U U \mathrm{~kg} / \mathrm{m}^{-}$total powder content. I hese results also inaicate that the risk of blockage is reduced by providing adequate viscosity, through the use of high powder. content; that ensuring good suspension of solid particles during deformation of the concrete. This may reduce inter-particles friction, which limits deformability in narrow spaces and. reduce the filling ability of concrete.

The segregation test results of the different concrete mixes with different contents of powder: and Viscocrete admixture are shown in Figs. 16, 17. In all mixes, the difference between the amounts of coarse aggregate in lower and upper sections is always lower than $9.4 \%$, which is below the limit for SCC (10\%). Figure 16 shows that there is no direct relationship between the dosage of admixture and segregation resistance for mixes type 1 to 4 . For concretes containing $500-600 \mathrm{Kg} / \mathrm{m}^{3}$, increasing the total powder content resulted in increasing segregation resistance, as shown in Fig. 17.

The 28-day compressive strength of all mixes is shown in Figs. 18, 19. Figure 18 shows, as expected; that the concrete mixes with the highest cement content gave the highest compressive strength. The presence of $2 \%$ admixture content clearly improved the strength, whatever the cement content might be. This improvement in strength may be due to the increased self-compactibility of concrete that may ensure high filling capacity, destroy the formation of internal pores and provide uniformity of mechanical properties. In Fig. 19, it can be observed that the variation of strength is proportional to the total powder content. This result indicated that SCC presenting a 28-day strength in the range of 250 to $300 \mathrm{Kg} / \mathrm{cm}^{2}$ can be obtained by the use of $350 \mathrm{Kg} / \mathrm{m}^{3}$ cement combined with 150 to $250 \mathrm{Kg} / \mathrm{m}^{3}$ powdered homra:

During demolding of concrete cubes, it is observed that the addition of powdered homra to the mix extended the setting time of concrete. Therefore, the setting times of cement with homra pastes and mortar are measured using the electrical conductivity-time curves [16] (Fig. 20). It is found that the partial replacement of OPC by homra prolonged the initial setting time from 23 to 43 minutes and the final setting time from 200 to 320 minutes for the cement paste. For mortars, it elongated the initial setting time from 82 to 98 minutes and the final setting time from 275 to 364 minutes. The retardation in the setting times may be due to decreasing the amount of cement clinker, which has faster setting properties in comparison with homra.

\section{CONCLUSIONS}

Based on the above results, the following conclusions have been reached:

1. The right dosage of Viscocrete: admixture in SCC with a total powder content of 400 $\mathrm{Kg} / \mathrm{m}^{3}$ is $2 \%$. This dosage can ensure both a high flowability and an adequate - viscosity that prevent the settlement of coarse aggregate particle and maintain the. uniformity of the concrete.

2. The use of high powder content $\left(500-600 \mathrm{Kg} / \mathrm{m}^{3}\right)$ increased both the yield value and viscosity of the mix; while the superplacticizer primarily reduced the yield value. The resulting combination can secure a mixture with a low yield value and a moderate viscosity, which are necessary for the successful casting of SCC.

3. Addition of homra powder as a replacement part of cement resulted in a slight reduction in the concrete flowability, noticeable decrease in compressive strength and prolonged initial and final setting times of concrete.

4. Self-compacting concrete with strength of $250-300 \mathrm{Kg} / \mathrm{cm}^{2}$ can be obtained by the use of $350 \mathrm{Kg} / \mathrm{m}^{3}$ cement combined with $150-250 \mathrm{Kg} / \mathrm{m}^{3}$ powdered homra. 


\section{REFERENCES}

in

1. Okamura, H. and Ozawa, K., "Mix Design for Self-Compacting Concrete", Conorete Library of JSCE, No. 25, 1995, pp. 107-120.

2." Abdel-Rahman, A.G. and Blaha, M.M., "Properties of Self-Compacting Concrete in the .Fresh State", Engineering Research Journal; Vol. 25, No. 1, January 2002, pp. 95:105;

3. Abdel-Rahman, A.G., "Mechanical Properties of Self-Compacting Concrete", Engineering Research Journal, Vol. 25, No. 2, April 2002; pp. 1-1.1.

4. Nasr, E.A., "Effect of Mix Proportions on the Slump Flow of Self-Compacting Concrete", Civil Engineering Research Magazine (CERM), Vol: 23, No. 3, July 2001, pp. 832-839.

5. Balaha, M.M., "Influence of Type and Content of Fibers on the Performance of SelfCompacting Concrete", Engineering Research Journal, Vol. 24, No. 4; October 2001, pp. 233-244.

6. Khayat, K., Hu, C. and Monty, H., "Stability of Self-Consolidating Concrete, Advantages and Potential Applications", Proceeding of the $1^{\text {st }}$ International RILEM Symposium on Self-Compacting Concrete, Edited by Sharendahl and Petersson, Stockholm, Sweden, Sept. 13-14, 1999, pp. 143-152.

7. Ambroise, J. and Péra, J., "Properties of Self-Leveling Concrete: Influence of a Viscosity Agent and Cement Content", Proceeding of the $5^{\text {th }}$. CANMET/ACI International Conference on Recent Advances in Concrete Technology; Edited by Malhotra, USA, JulyAugust 2001, pp. 367-380.

8. Poppe, A.M. and Schutter, G.De, "Influence of the Nature and Grading Curve of the Powder on the Rheology of Self-Compacting Concrete", Proceeding of the $5^{\text {th }}$ CANMET/ACI International Conference on Recent Advances in Concrete Technology, Edited by Malhotra, USA, July-August 2001, pp. 399-414.

9. Yahia, A., Tanimura, A., Shimabukuro, A. and Shimoyama, Y., "Effect of Rheological Parameters on Self-Compactability of Concrete Containing Various Mineral Admixtures", Proceeding of the $1^{\text {st }}$ International RILEM Symposium on Self-Compacting Concrete, Edited by Sharendahl and Petersson, Stockholm, Sweden, Sept. 13-14, 1999, pp. 523-535.

10. Takada, K., Pelova, G.I. and Walraven, J.C., "Effect of Micro-Fillers on Proportioning of Mortar in Self-Compacting Concrete", Proceeding of the $1^{\text {st }}$ International RILEM Symposium on Self-Compacting Concrete, Edited by Sharendahl and Petersson, Stockholm, Sweden, Sept. 13-14, 1999, pp. 537-548.

11. Fang, W., Jianxiong, C. and Changhui, Y., "Studies in Self-Compacting High, Performance Concrete with High Volume Mineral Additives", Proceeding of the "1 $1^{\text {st }}$ International RILEM Symposium on Self-Compacting Concrete, Edited by Sharendahl and Petersson, Stockholm, Sweden, Sept. 13-14, 1999, pp. 569-578.

12. Kasami, H., Hosino, M., Arasima, T. and Tateyasiki, H., "Use of Recycled Concrete Powder in Self-Compacting Concrete", Proceeding of the $5^{\text {th }}$ CANMET/ACI InternationalConference on Recent Advances in Concrete Technology, Edited by Malhotra, USA, July-. August 2001, pp. 381-397.

13. Xincheng, P., Jianxiong, C. and Yubin, H., "Preparing Technique of Super High Strength, High Performance Concrete with Superfine Sand", Journal of Changqing Jianzhu. University, Vol. 21, No. 1, 1999, pp. 1-4.

14. Jianxiong, C., Xincheng, P. and Yubin, H., "A Study of Self-Compacting HPC with" Superfine Sand and Pozzolanic Additives", Proceeding of the $1^{\text {st }}$ International RILEM Symposium on Self-Compacting Concrete, Edited by Sharendahl and Petersson, Stockholm, Sweden, Sept. 13-14, 1999, pp. 549-560.

15. Hewlett, P.C., "Lea's Chemistry of Cement and Concrete", $4^{\text {th }}$ Edition, Edward Arnold;"s London, 1998, pp. 903-989. 
16. Heikal, M., Morsy, M.S. and Abo-El-Enein, S.A., "Electrical Conductivity of Pozzolanic Cement Pastes and Mortars Containing Crushed Clay Bricks (Homra)", $15^{\text {th }}$ Egyptian Chemistry Conference, 20-25 Nov. 1999, pp. 145-152.

17. El-Didamony, H., Heikal, M. and Shoaib, M.M., "Homra Pozzolanic Cement", Silicates Industrials, Ceramic Science and Technology, Vol. 65, No. 3-4, March-April 2000, pp. 39-43.

18. Heikal, M., El-Didamony, H. and Ali, A.H., "Pozzolanic Action of Homra with Lime", Indian Journal of Engineering and Materials Sciences, Vol. 7, June 2000, pp. 154-159.

19. Heikal, M., El-Didamony, H. and Morsy, M.S., "Limestone-Filled Pozzolanic Cement", Cement and Concrete Research, Vol. 30, 2000, pp. 1827-1834.

20. Heikal, M., "Effect of Temperature on the Physico-Mechanical and Mineralogical Properties of Homra Pozzolanic Cement Pastes", Cement and Concrete Research, Vol. 30, 2000, pp. 1835-1839.

21. Sonebi, M. and Bartos, P., "Performance of Reinforced Columns Cast with SelfCompacting Concrete", Proceeding of the $5^{\text {th }}$ CANMET/ACI International Conference on Recent Advances in Concrete Technology, Edited by Malhotra, USA, July-August 2001, pp. 415-431.

22. Van, B.K., Montgomery, D.G., Hinczak, I. and Turner, K., "Rapid Testing Method for Segregation Resistance and Filling Ability of Self-Compacting Concrete", Proceeding of the $4^{\text {th }}$ CANMET/ACI/JCI International Symposium on Advances in Concrete Technology, Tokushima, Japan, Edited by Malhotra, ACI SP 179, 1998, pp. 85-104.

\section{استخدام بودرة الحمرة فى الخرسائة ذاتية الامكك}

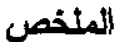

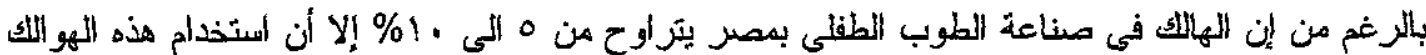

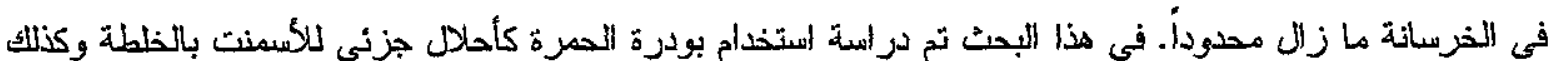

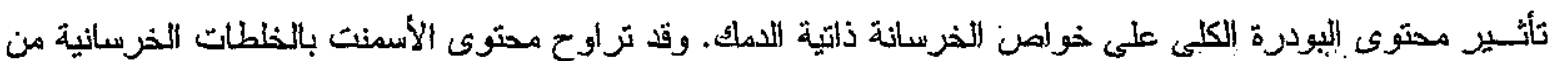

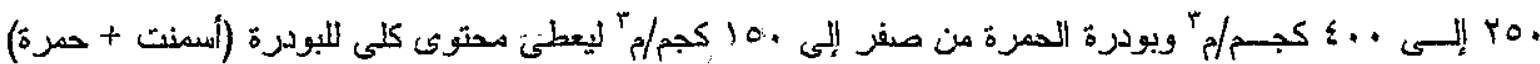

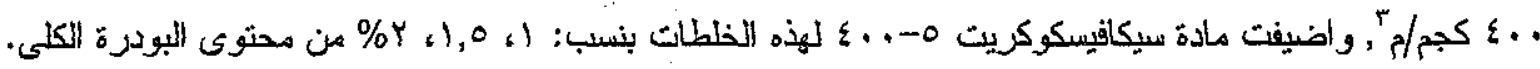

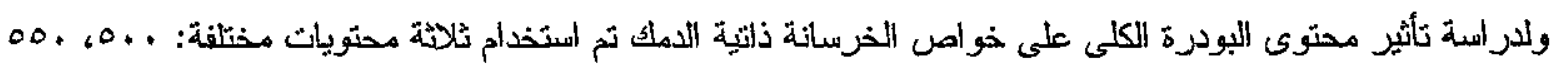

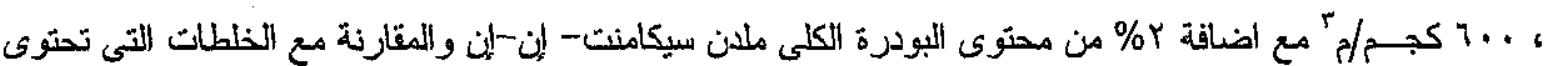

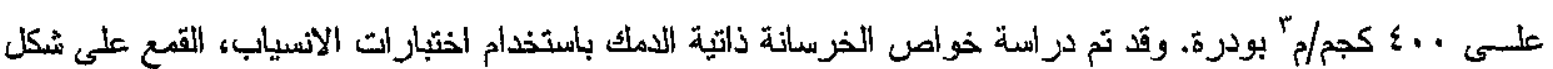

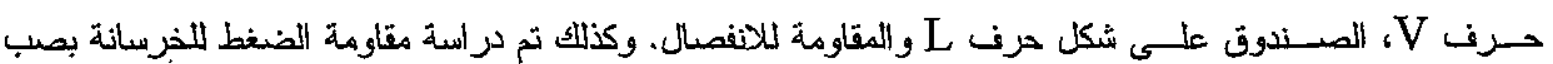

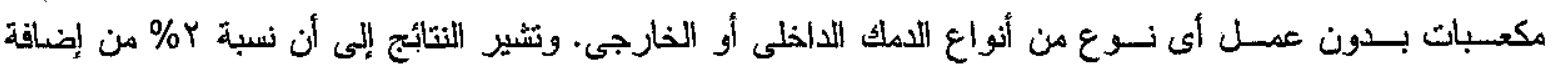

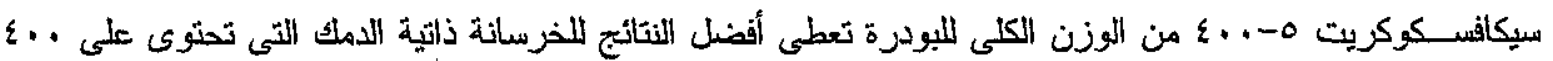

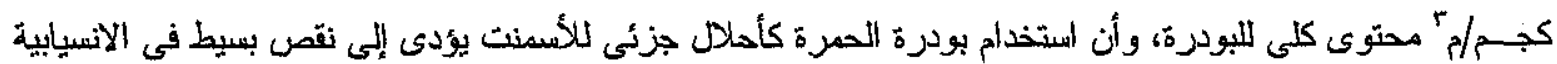

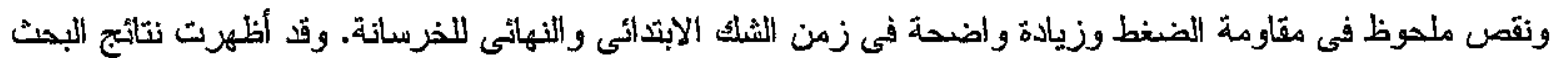

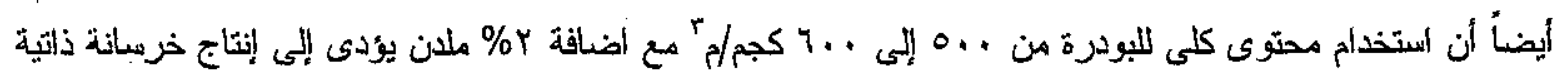
الدمك ذات أداء متميز حيث تحقق انسيابية عالية ولزوجة معتدلة. 
Table 1. Chemical Composition of OPC, Homra and Clay

\begin{tabular}{|c|c|c|c|c|c|c|c|}
\hline \multirow{2}{*}{ Oxides } & \multicolumn{7}{|c|}{ Chemical Composition (wt\%) } \\
\cline { 2 - 8 } & $\mathrm{SiO}_{2}$ & $\mathrm{Al}_{2} \mathrm{O}_{3}$ & $\mathrm{Fe}_{2} \mathrm{O}_{3}$ & $\mathrm{CaO}$ & $\mathrm{MgO}$ & $\mathrm{SO}_{3}$ & LOI \\
\hline OPC & 20.50 & 5.05 & 2.89 & 62.00 & 2.07 & 2.40 & 3.10 \\
\hline Homra & 74.80 & 14.03 & 5.04 & 1.25 & 1.30 & 1.80 & - \\
\hline Clay & 49.34 & 22.24 & 9.47 & 0.56 & 2.21 & 0.19 & - \\
\hline
\end{tabular}

Table 2. Concrete Mix Proportions $\left(\mathrm{Kg} / \mathrm{m}^{3}\right)$

\begin{tabular}{|c|c|c|c|c|c|c|c|c|c|}
\hline $\begin{array}{c}\text { Mix } \\
\text { No. }\end{array}$ & Cement & $\begin{array}{c}\text { Powdered } \\
\text { homra }\end{array}$ & Sand & $\begin{array}{c}\text { Coarse } \\
\text { agg. }\end{array}$ & Water & $\begin{array}{c}\text { Total } \\
\text { powder }\end{array}$ & W/P & W/C & $\begin{array}{c}\text { Type of } \\
\text { admixture }\end{array}$ \\
\hline 1 & 400 & - & 900 & 800 & 200 & 400 & 0.50 & 0.50 & ViscoCrete \\
\hline 2 & 350 & 50 & 900 & 800 & 200 & 400 & 0.50 & 0.57 & ViscoCrete \\
\hline 3 & 300 & 100 & 900 & 800 & 200 & 400 & 0.50 & 0.67 & ViscoCrete \\
\hline 4 & 250 & 150 & 900 & 800 & 200 & 400 & 0.50 & 0.80 & ViscoCrete \\
\hline 5 & 350 & 150 & 900 & 800 & 200 & 500 & 0.40 & 0.57 & Sikament-NN \\
\hline 6 & 350 & 200 & 900 & 800 & 200 & 550 & 0.36 & 0.57 & Sikament-NN \\
\hline 7 & 350 & 250 & 900 & 800 & 200 & 600 & 0.33 & 0.57 & Sikament-NN \\
\hline
\end{tabular}

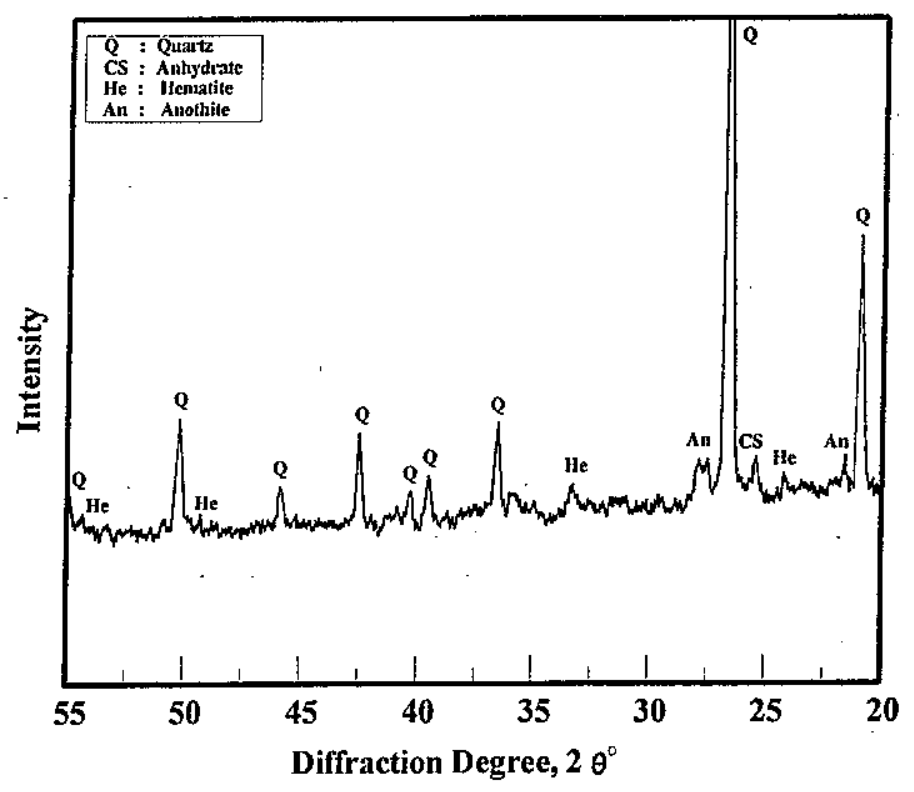

Fig. 1. XRD Pattern of Clay Bricks (Homra). 


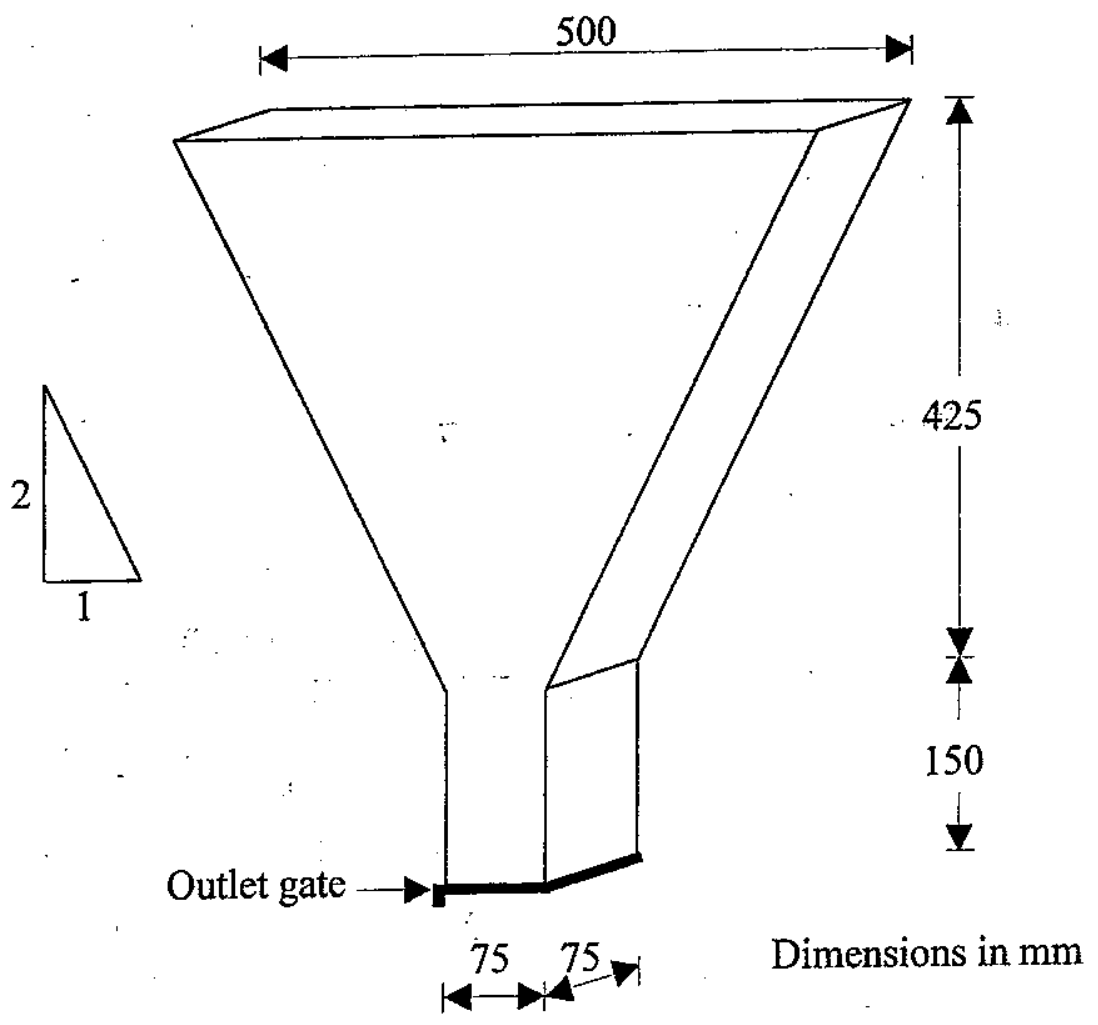

Fig. 2. V-Funnel Apparatus.

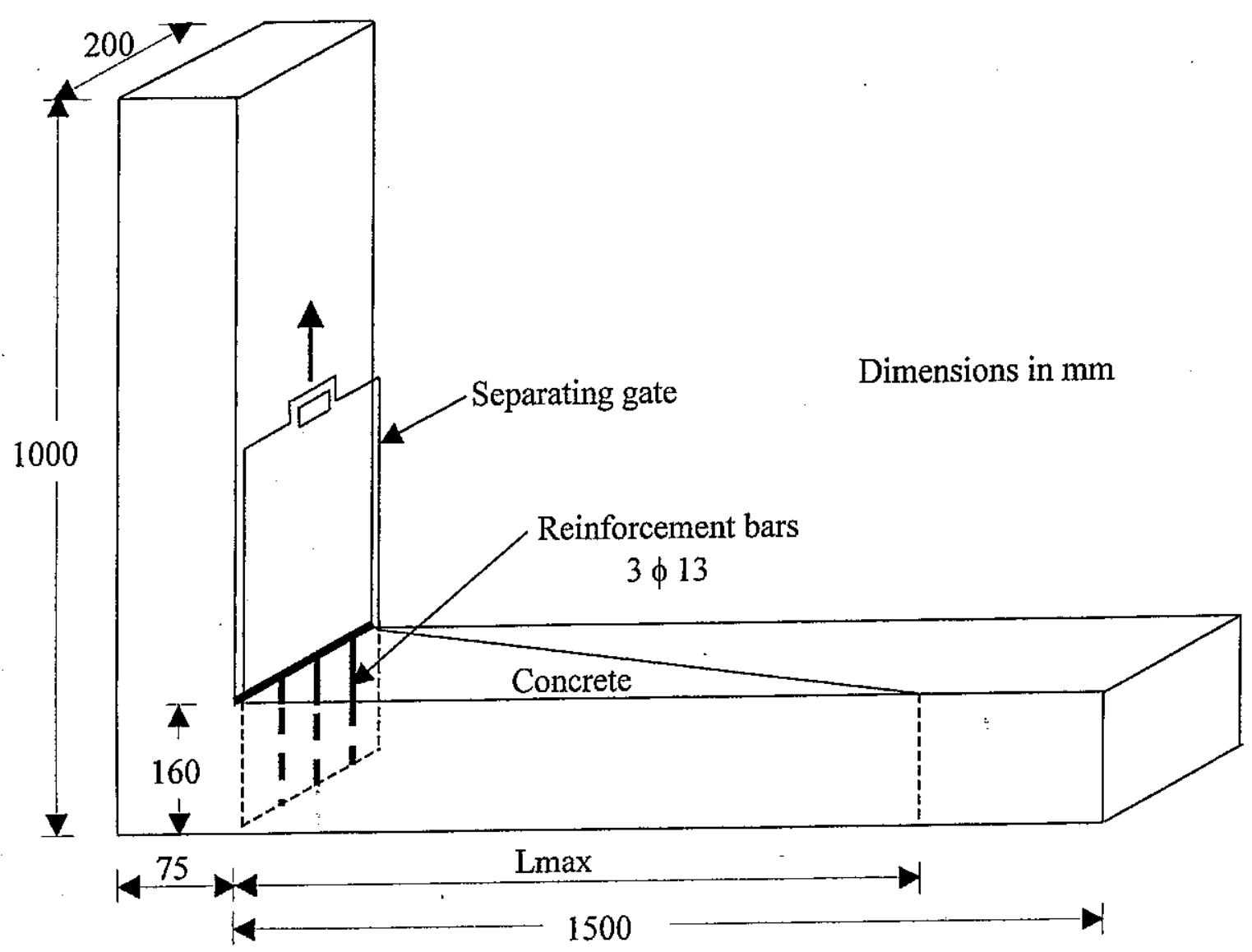

Fig. 3. L-Box Apparatus. 


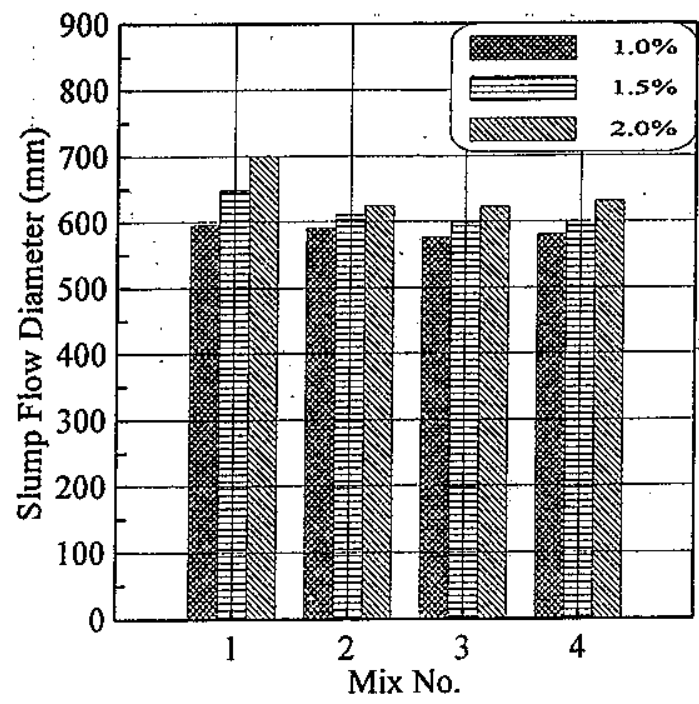

Fig. 4. Slump Flow Diameter of Different Mixes.

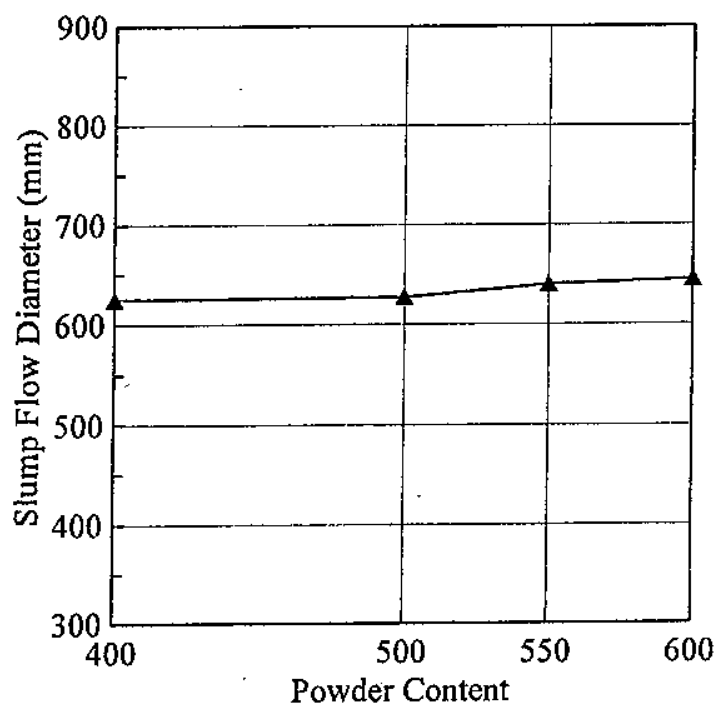

Fig. 6. Slump Flow Diameter vs Powder Content.

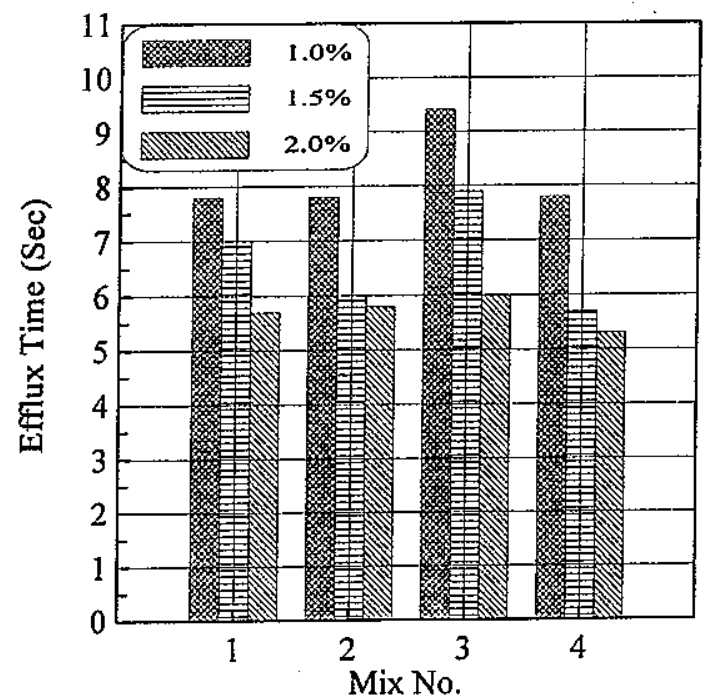

Fig. 8. V-Funnel Flow Time of Different Mixes.

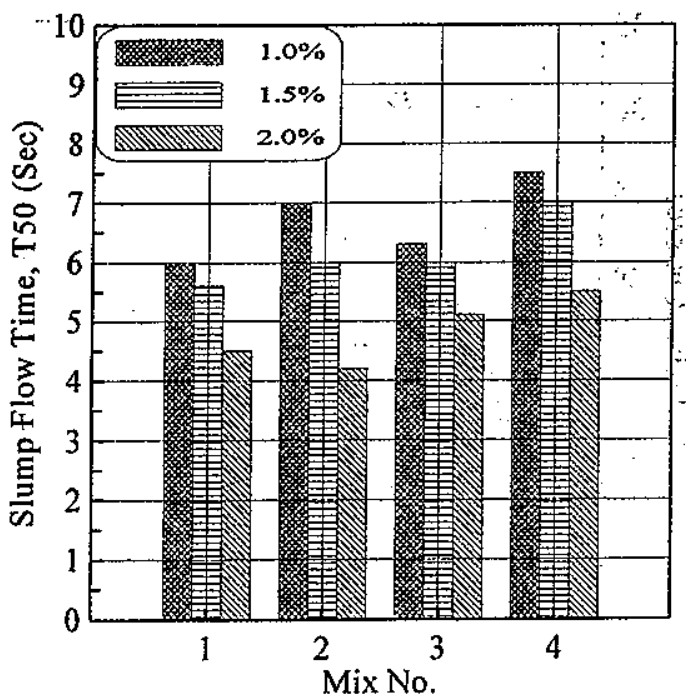

Fig. 5. Slump Flow Time of Differet Mixes.

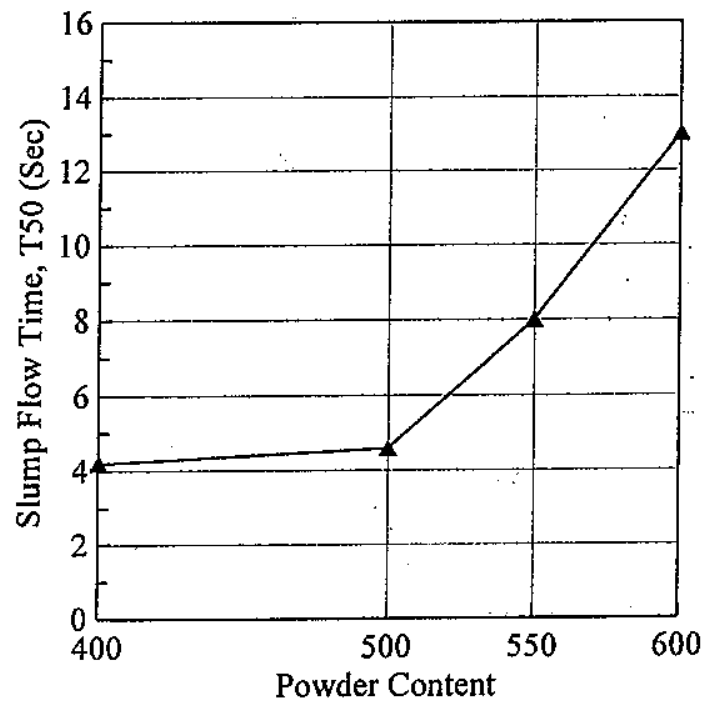

Fig. 7: Slump Flow Time vs Powder Content.

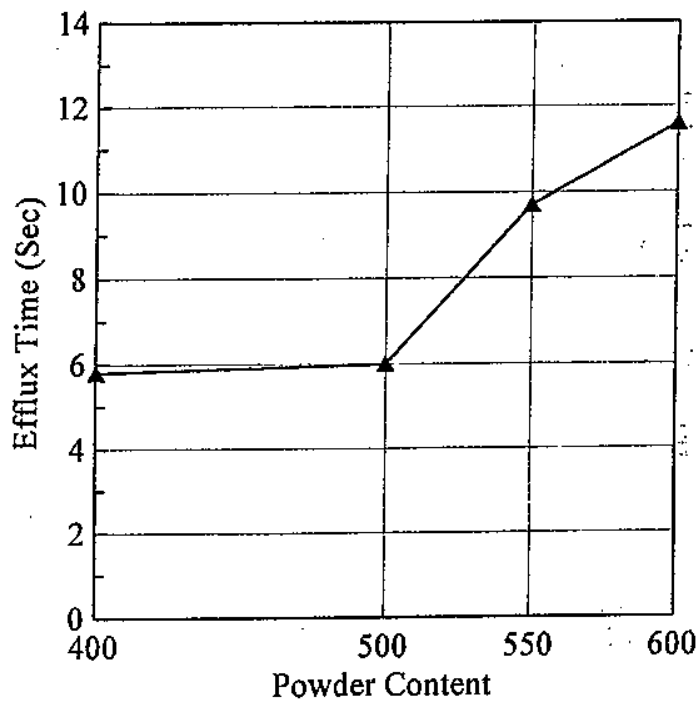

Fig: 9. V-Funnel Flow Time vs Powder Content 


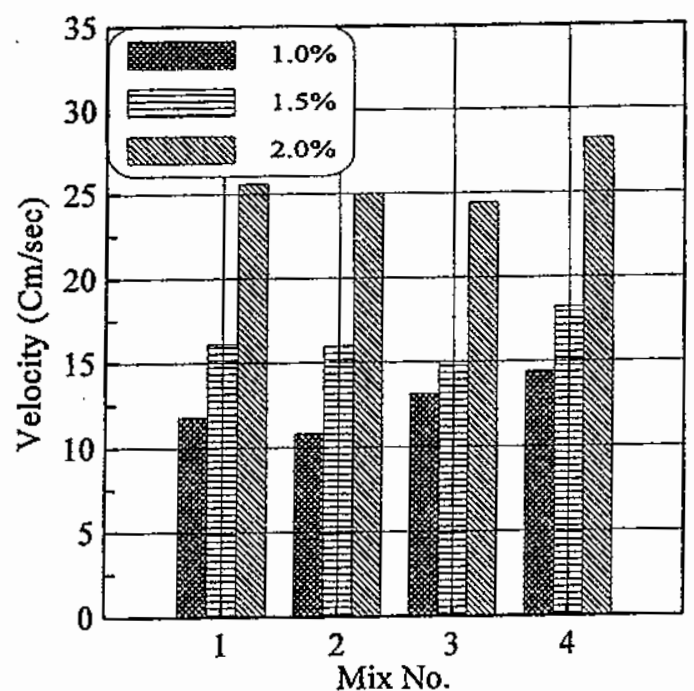

Fig. 10. Spread Velocity of Different Mixes.

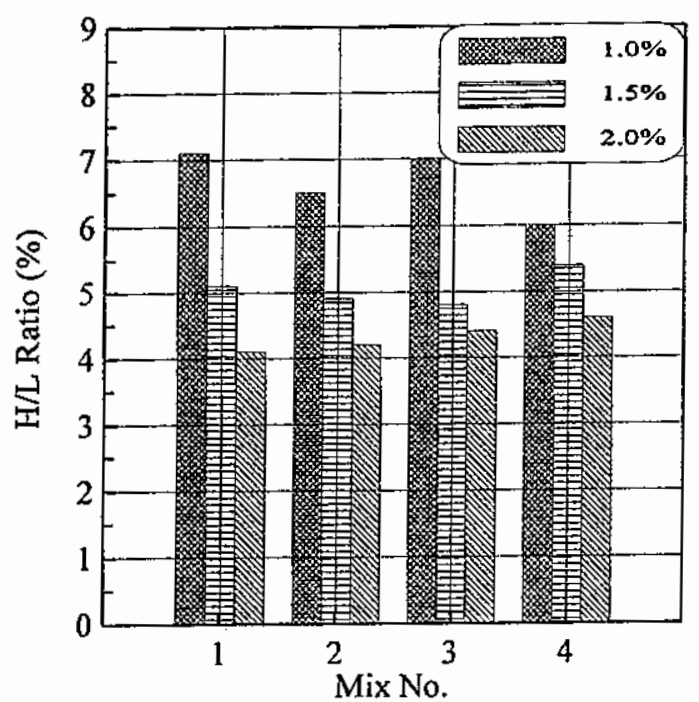

Fig. 12. H/L Ratio of Different Mixes.

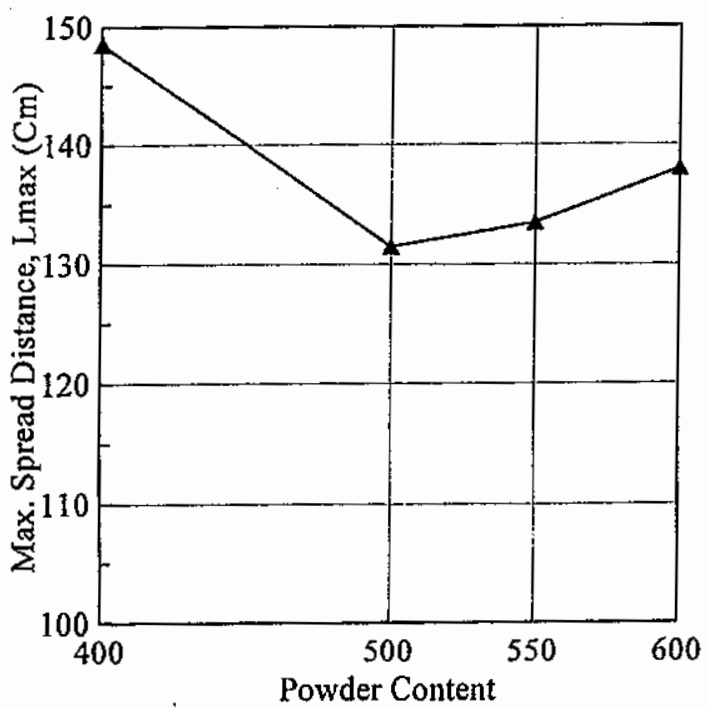

Fig. 14. Spread Distance vs Powder Content.

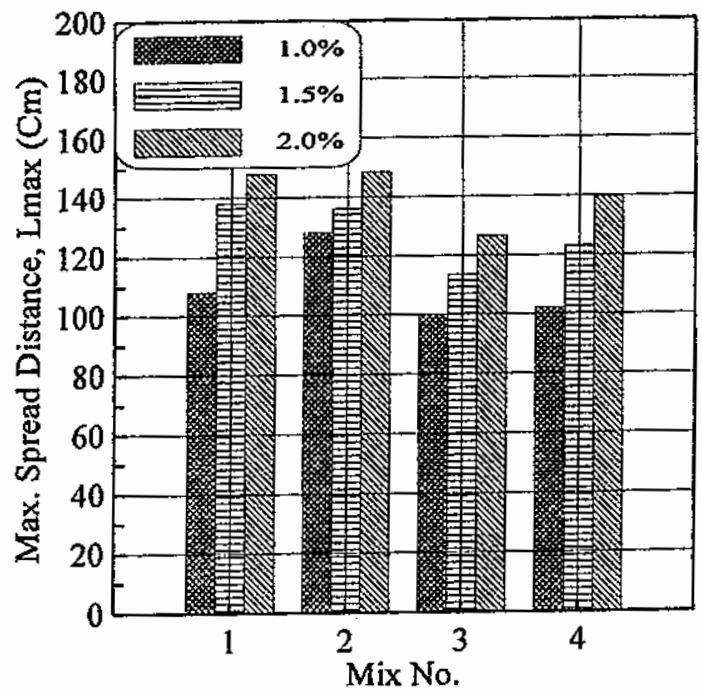

Fig. 11. Spread Distance of Different Mixes.

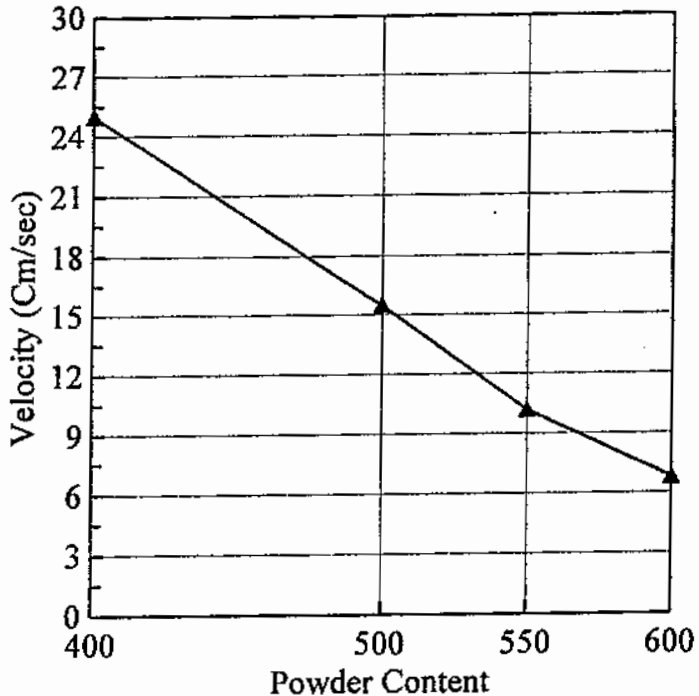

Fig. 13. Spread Velocity vs Powder Content.

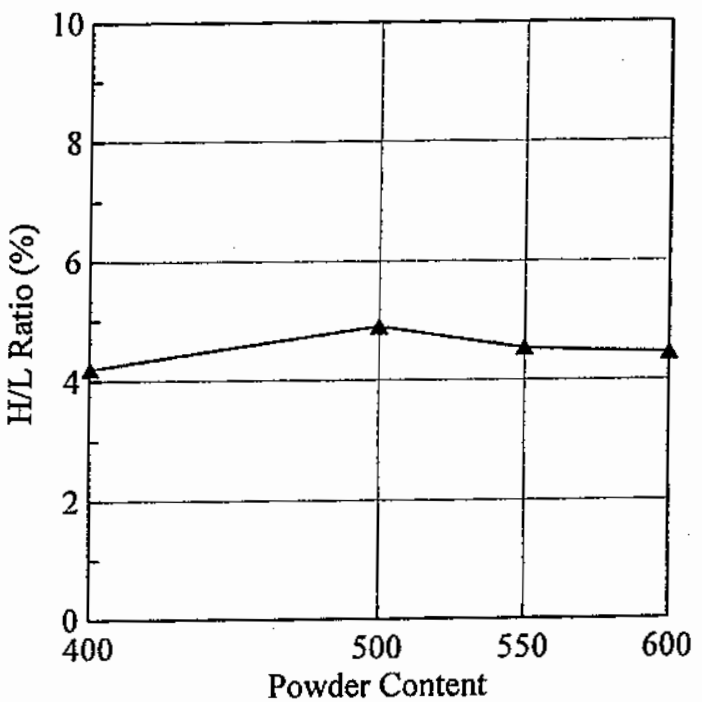

Fig. 15. H/L Ratio vs Powder Content. 


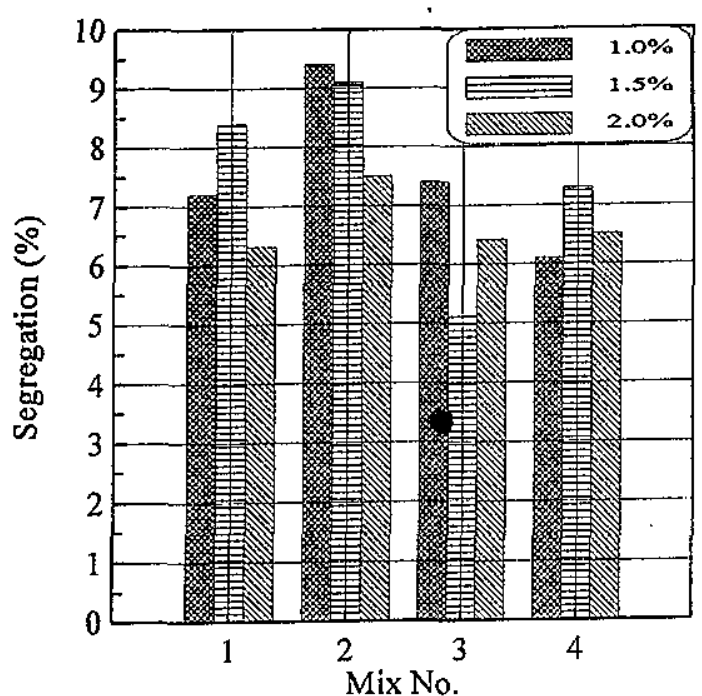

Fig. 16. Segregation of Different Mixes.

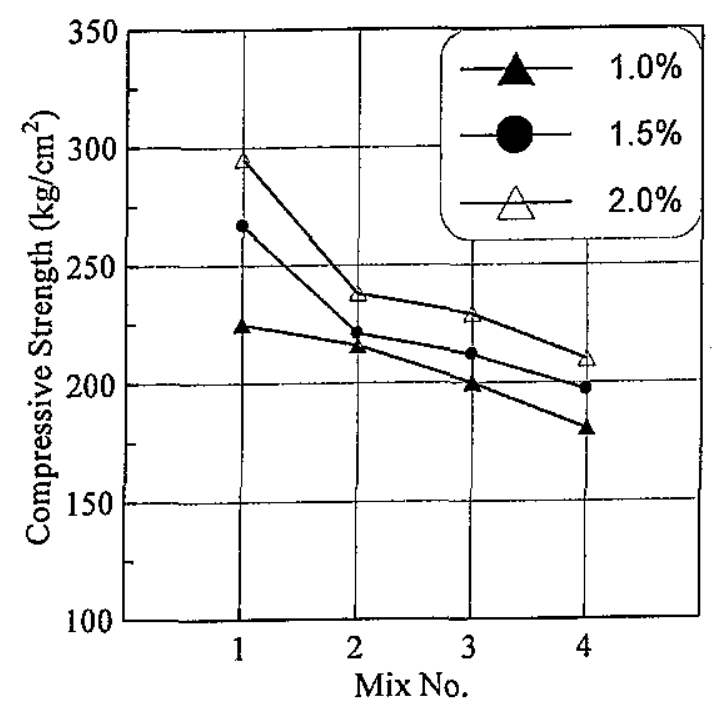

Fig. 18. Compressive Strength of Different Mixes.

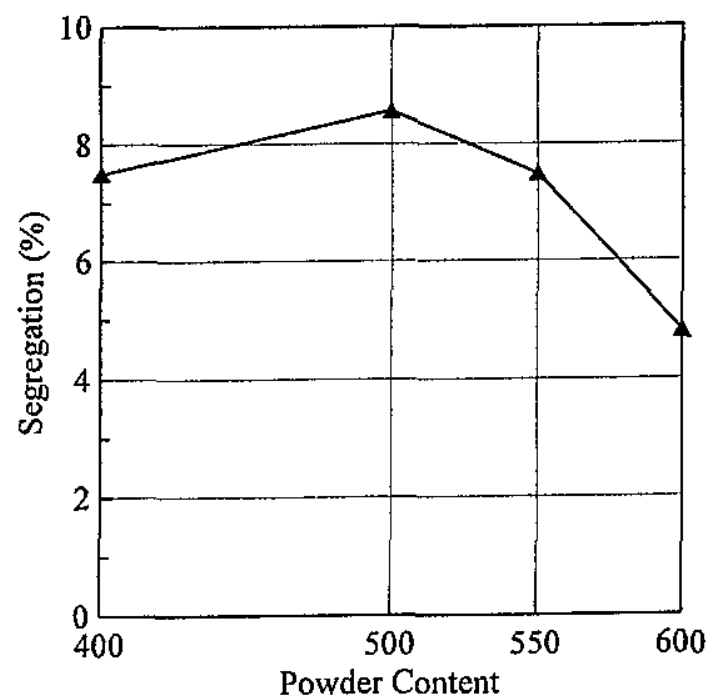

Fig. 17. Segregation vs Powder Content.

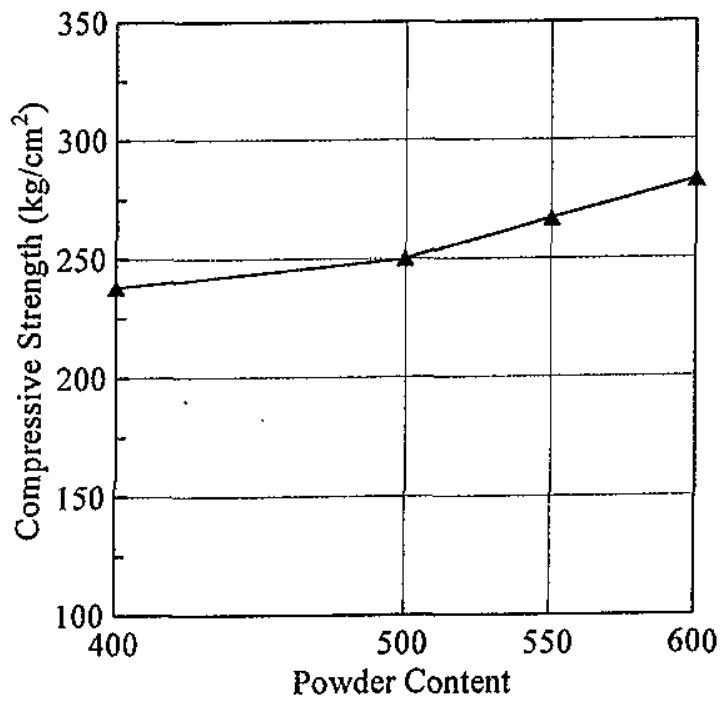

Fig. 19. Comp. Strength vs Powder Content.

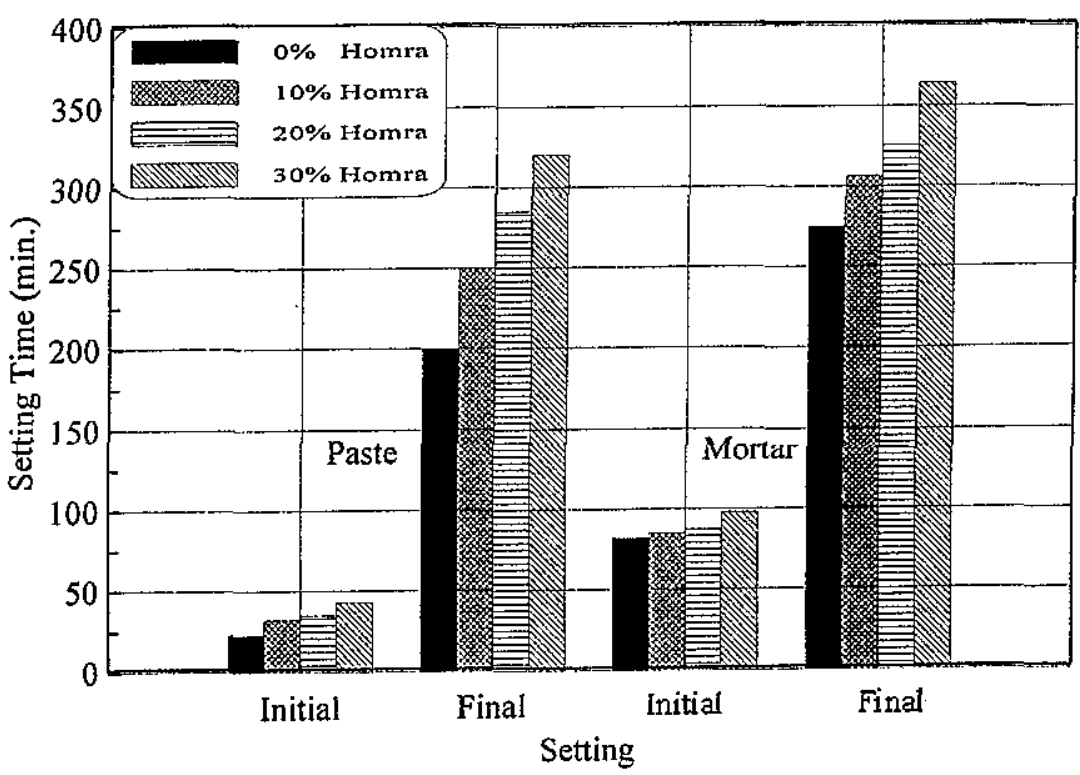

Fig. 20. Settimg Times of Cement Paste and Mortar Containing Homra. 